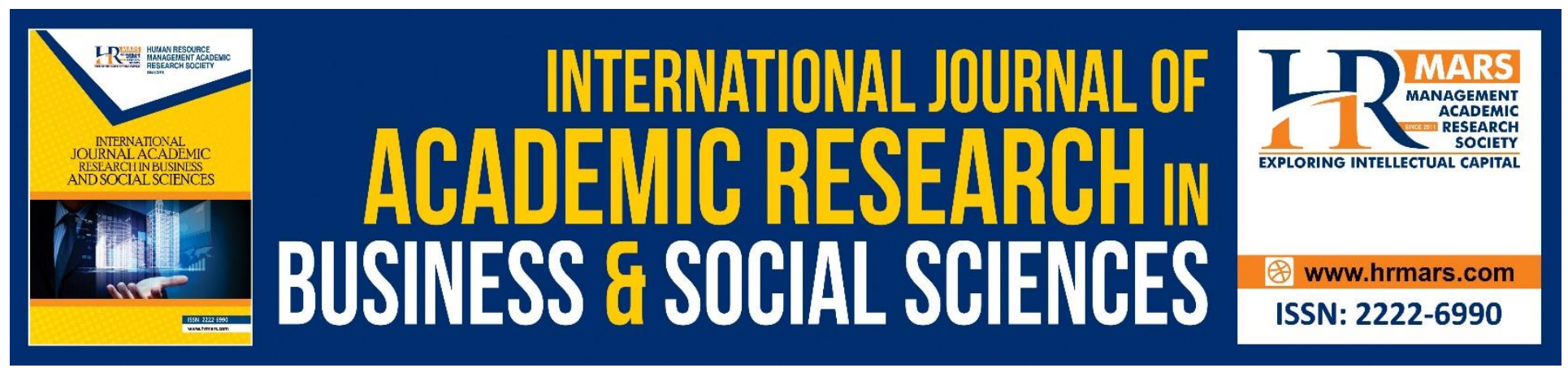

\title{
Factors Affecting Deviant Behaviour At Workplace Among Young Public Sector Employees
}

\author{
Jeffrey Lawrence D'Silva, Azham Bachok, Dahlia Zawawi
}

To Link this Article: http://dx.doi.org/10.6007/IJARBSS/v10-i15/8242

DOI:10.6007/IJARBSS/v10-i15/8242

Received: 13 September 2020, Revised: 16 October 2020, Accepted: 12 November 2020

Published Online: 29 November 2020

In-Text Citation: (D'Silva et al., 2020)

To Cite this Article: D'Silva, J. L., Bachok, A., \& Zawawi, D. (2020). Factors Affecting Deviant Behaviour At Workplace Among Young Public Sector Employees. International Journal of Academic Research in Business and Social Sciences, 10(15), 176-188.

Copyright: (c) 2020 The Author(s)

Published by Human Resource Management Academic Research Society (www.hrmars.com)

This article is published under the Creative Commons Attribution (CC BY 4.0) license. Anyone may reproduce, distribute, translate and create derivative works of this article (for both commercial and non-commercial purposes), subject to full attribution to the original publication and authors. The full terms of this license may be seen

at: http://creativecommons.org/licences/by/4.0/legalcode

Special Issue: Youth and Community Wellbeing: Issues, Challenges and Opportunities for Empowerment V1, 2020, Pg. 176 - 188

Full Terms \& Conditions of access and use can be found at http://hrmars.com/index.php/pages/detail/publication-ethics 


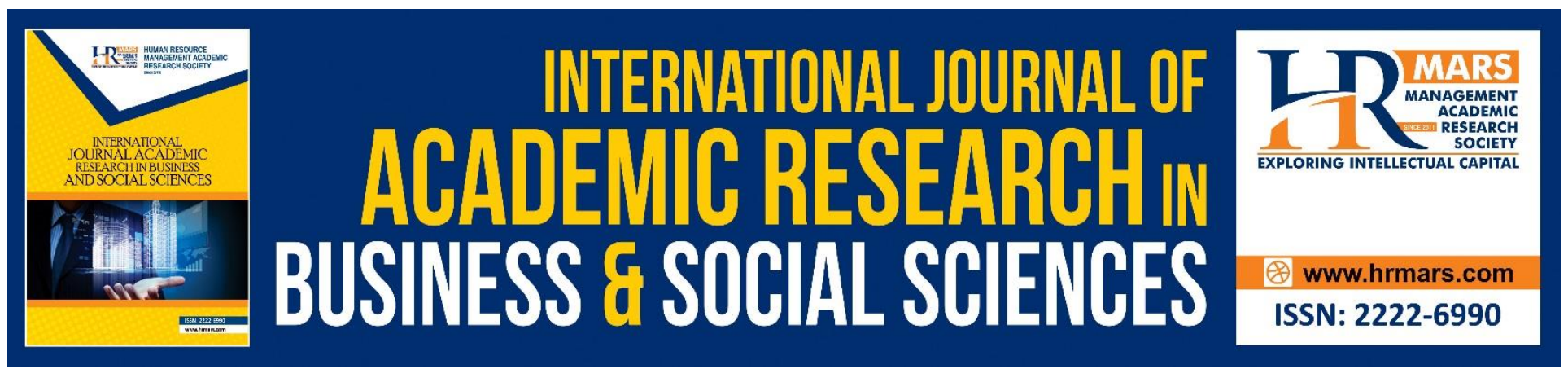

\title{
Factors Affecting Deviant Behaviour At Workplace Among Young Public Sector Employees
}

\author{
Jeffrey Lawrence D'Silva, Azham Bachok \\ Institute for Social Science Studies, Universiti Putra Malaysia, 43400 Serdang, Selangor, Malaysia \\ Email: jld@upm.edu.my, azhambachok@gmail.com
}

\section{Dahlia Zawawi}

Institute for Social Science Studies, Universiti Putra Malaysia, 43400 Serdang, Selangor, Malaysia School of Business and Economics, Universiti Putra Malaysia, 43400 Serdang, Selangor, Malaysia

Email: dahlia@upm.edu.my

\begin{abstract}
Deviant workplace behaviour phenomenon is increasingly becoming popular and this issue had attracted many researchers to study the phenomenon as its' impacts are huge on employees productivity and well-being. The purpose of this article is to identify factors that affect workplace deviant behaviour among young public sector employees. A review was conducted to obtain the data. The findings revealed that a number of factors and these factors could be further investigated among future researchers to understand and address the complexities associated with workplace deviant behaviour and to identify predictive factors that could explain the phenomenon of workplace deviant behaviour among young public sector employees.
\end{abstract}

Keywords: Deviant Behaviour, Employee, Framework, Workplace, Work Productivity

\section{Introduction}

In the past decades, researchers and managers have constantly investigated the phenomenon of deviant behaviour at workplace. Basically, workplace deviant behaviour means misbehaviour in the workplace and it could be categorized into aggressive behaviour (sexual harassment, intimidation, or showing open hostility towards co-workers), unproductive behaviour (showing up late for work, taking extended lunch or coffee breaks, or sneaking out early), abuse of property, and organization politics (spreading false rumours or gossips) (Joseph, 2020). Workplace deviant behaviour is not a new issue to discuss. However, the resources which examined deviant behaviour at workplace are still growing and show many new dimensions to investigate within the parameters of time and circumstances. The literature review of various scholars has defined workplace deviant behaviour (Appelbaum et al., 2007) and clarified the outcomes of deviant workplace behaviours. But studies 
INTERNATIONAL JOURNAL OF ACADEMIC RESEARCH IN BUSINESS AND SOCIAL SCIENCES

Vol. 10, No. 15, Youth and Community Wellbeing: Issues, Challenges and Opportunities for Empowerment V1. 2020, E-ISSN: 2222-6990 @) 2020 HRMARS

regarding workplace deviant behaviours are still needed to be considered especially at different organizations (Yildiz et al., 2015). Workplace deviant behaviours, primarily that are destructive in nature, are among the important determinants affecting well-being of organizational norms and performance.

Almost all organizations face the phenomenon of deviant behaviour at workplace. Novallien (2017) states that issues pertaining to workplace deviant behaviour and attitude of workers are becoming prominent lately with emergence of new issues and the quest for higher productivity. Employees were found to display deviant behaviours at workplace due to a myriad of factors and this could be due to personal or organizational factors or a combination of both. Additionally, Robinson and Bennet (1995) mentioned that there are two perspectives to depict deviant behaviour and this could be categorized into organizational deviance and interpersonal deviance. In line with this, deviant behaviour is recognized as a dual interaction between organizational affects as well as individual affects that would impact individuals to display behavioural deviance. Organizations that are able to tackle deviant workplace behaviour were able to identify strategies based on the recognition of relationship between organizational and interpersonal deviances (Robinson, Robertson \& Curtis, 2012).

Past literature revealed that there are many definitions to explain workplace deviant behaviour. In fact, Robinson and Greenberg (1995) state that there is no common definition to describe workplace deviant behaviour. One of the popular definitions is the one provided by Robinson and Bennett (1955) that defined deviant workplace behaviour as "a voluntary behaviour engaged by employee that is contrary to the significant organizational norms and it is considered as a threat to the well-being of an organization and/or its members". On the other hand, workplace deviant behaviour is described as any action or behaviour among individuals that lead to chaos, unrest and harm to other employees, concerned organization and its' stakeholders (Henle, Giacalone, \& Jurkiewicz, 2005; Giacalone \& Greenberg, 1997). In addition, Robinson and Bennet (1995) clarifies that workplace deviant behaviour is pictured as 'voluntary behaviour of organizational members that violates significant organizational norms and in so doing, threatens the well-being of the organization and/its members'. Thus, deviant workplace behaviour is perceived as a source that will have a negative impact towards employees and organization as a whole and this impact ranges from negligible to extremely significant.

Over the years, organizational workplace deviant behaviour has been studied extensively under different terms (Javed \& Amjad, 2014). Among similar terms used in past research to describe workplace deviant behaviour are misbehaviour in organization, counterproductive workplace behaviour, retaliation, antisocial behaviour, employee resistance, non-compliant behaviour, negative behaviour in organization, and dysfunctional behaviour (Tepper, Duffy \& Shaw, 2001). Past studies show that individuals display deviant behaviour as a result of superior abuse, or being unhappy at workplace and consequently deviances occur at the production department or on other resources in an organization (Hollinger, 1986).

A number of theories were used as the foundation in studies pertaining to workplace deviant behaviour. One of the most prominent theories is the Social Learning Theory (SLT) advocated by Bandura (1977). In this theory, ethics is deemed as the important predictor towards intention to practice deviant behaviour. The theory further postulates ethical leadership would enable leaders in 
organizations to demonstrate apt behaviour that will be emulated by the subordinates as well as leaders learning via observation on employees' positive values, and embracing these values in the organization. Being a role model in organization, leaders are able to push employees with the rewardpunishment mechanism and consequently employees will abide by the rules and regulations of the organization. Recent studies carried out by offer statistical evidence on the inverse relationship between ethical leadership and intention to practice deviant behaviour (Aryati et al., 2017; Sims, 2002). Moreover, SLT likewise emphasizes the importance of role modelling whereby good values practiced in organizations will have a chain effect on employees. Leaders are pictured as legitimate models for good values in organizations. Besides, since leaders have the authority to impose punishments as well as giving rewards for employees' behaviour that is unethical and ethical respectively, they have to demonstrate possessing exemplary virtues. SLT also sees organizations as a place of continuous learning and consequently employees must attain knowledge on organizational ethical behaviour via observing the environment besides their own experiences (Bandura, 1986).

Another prominent theory to understand employer behaviour is the Social Exchange Theory (Crozpanzo \& Mitchell, 2005) developed by Blau (1986). The theory states that there are two predictors of employees' behaviour, namely, organizational citizenship behaviour and perceived organizational support. In this theory, much importance is placed towards the cordial relationship between employer and employees' behaviour and attitude (Coyle, Shapiro \& Conway, 2005). Hence, according to this theory, dissatisfaction among individuals or employees is a result of receiving poor treatment from superiors or leaders in organizations. Employees are prone to demonstrate disparaging behaviours if they have to face harsh and unpleasant working conditions in organizations.

General Strain Theory (GST) (Agnew, 2001) is another theory to explain deviant workplace behaviour. This theory implicates individuals' negative behaviours that can lead to deviant behaviour in the workplace. The main proponent of GST is Agnew (2001) and the strains as mentioned in this theory have three main components. The first component is about stimuli and goals whereby individuals could be affected due to not achieving the targeted goals, the existence of perilous stimuli or in the absence esteemed stimuli. Then, the second component is about the conditioning factors that have an influence on exhibiting behaviours that are either deviant or otherwise when one had to face strains. The last component expresses the notion that in the absence of positive adaptations and being overloaded with negative thoughts, individuals are prone to act defiantly to reduce the effect to the strain. This theory has been utilized by study involving various categories of sample such as government staff (Alias, 2013; Radzali, 2015) on various forms of workplace deviant behaviour research.

Another prominent theory that elucidates the workplace deviant behaviour is the social control theory (Hirschi, 1969). Subjective norms, especially family and religion, play a paramount role in this theory. The theory states that deviant behaviour could dramatically be reduced if family bondage and spirituality are emphasized among individuals. This theory can be used in examining the individuals' spiritual level towards their attitude and behaviour in the workplace. Deviation from social norms as explained by Hirschi (1969) is based on four specific concepts: attachment, commitment, involvement, and belief (Young \& Bucklen, 2011). Attachment, meaning the extent that a person is socially bonded to parents, peers, teachers, religious leaders and other community members is the most important element of the social bond (Young \& Bucklen, 2011). Commitment represents the social, professional and economic investment in conventional society. Involvement 
INTERNATIONAL JOURNAL OF ACADEMIC RESEARCH IN BUSINESS AND SOCIAL SCIENCES

Vol. 10, No. 15, Youth and Community Wellbeing: Issues, Challenges and Opportunities for Empowerment V1. 2020, E-ISSN: 2222-6990 @ 2020 HRMARS

refers to active participation in prosocial activities that leave less time for social deviance, based on the notion that "idle hands are the devil's workshop" (Young \& Bucklen, 2011). The fourth concept, belief, theorizes that the more someone believes in social norms, the less likely they are to behave contrary to them (Young \& Bucklen, 2011).

Undeniably, public sector have many young staff yet not much research had been carried out to identify the level of workplace deviation in this sector and its' influencing factors. Based on the theoretical understanding of deviant behaviour at workplace and past organizational research, this article aims to identify the dimensions that affect workplace deviant behaviour among young employees in the public sector.

\section{Workplace deviant behaviour and affecting factors}

A review of the past studies showed that there are several dimensions that have an effect on deviant behaviour at workplace as in Table 1.

Table 1: Studies on workplace deviant behaviour

\begin{tabular}{|c|c|}
\hline Dimensions & Supporting Studies \\
\hline Stress & $\begin{array}{l}\text { Wan Din (2015); Ibnu (2014); Farhadi (2011); } \\
\text { Adeoti, Shamsudin and Wan (2017); Abdul } \\
\text { Mutalib, Mohd Taib, Dina (2018); Omar, Halim, } \\
\text { Zainah, Farhadi, Nasir, Khairuddin (2011); Farah } \\
\text { Mardiana binti Radzali , (2015); Mohesn } \\
\text { Golparvar. (2015); Yan_Hong Yao and Ying- Ying } \\
\text { Fan, Yong-Xing Guo, Yuan Li. (2014) }\end{array}$ \\
\hline Job Satisfaction & $\begin{array}{l}\text { Hadi Farhadi (2011); Azlina Yassin, (2011); Mazni } \\
\text { Alias , (2013); Aminah Ahmad, Zoharah Omar } \\
\text { (2014); Misbah Nasir and Ambreen Bashir (2012); } \\
\text { Muharrem Tuna, Issam Ghazzawi; Murat Yesiltas, } \\
\text { Aysen Akbas Tuna and Siddik Arslan. (2014); } \\
\text { Fatimah Omar, F. W. Halim, A.Z Zainah, H. Farhadi, } \\
\text { R. Nasir, R. Khairuddin (2011) }\end{array}$ \\
\hline Spirituality & $\begin{array}{l}\text { Haldorai, Chang, Li (2020); Farah Mardiana binti } \\
\text { Radzali.(2015); Aulia Maulana Septa, Nasrillah } \\
\text { (2018); Abdul Mutalib Mohamad Azim, Mohd Taib } \\
\text { Dora, Dina Syamilah Zaid.(2018) Augustine } \\
\text { Acheampong \& Kingsley Agyapong (2015); Michael } \\
\text { Olalekan Adeoti, Faridahwati Mohd Shamsudin \& } \\
\text { Chong Yen Wan (2017); Abdul Rahman Abdul } \\
\text { Rahim, Ahmad Shazeer Mohamed Thaheer, Alwi } \\
\text { Shabudin, Abdul Rahman Abdul Wahab \& } \\
\text { Noorazmi Hashim (2014); Omar Khalid Bhatti, } \\
\text { Muhammad Aftab Alam, Arif Hassan, \& Mohamed } \\
\text { Sulaiman (2016); Aminah Ahmad, Zoharah Omar } \\
\text { (2014) }\end{array}$ \\
\hline
\end{tabular}


INTERNATIONAL JOURNAL OF ACADEMIC RESEARCH IN BUSINESS AND SOCIAL SCIENCES

Vol. 10, No. 15, Youth and Community Wellbeing: Issues, Challenges and Opportunities for Empowerment V1. 2020, E-ISSN: 2222-6990 @ 2020 HRMARS

\begin{tabular}{|c|c|}
\hline Dimensions & Supporting Studies \\
\hline Perceived Organizational Support & $\begin{array}{l}\text { Lim Li Chen, Benjamin Chan Yin Fah, Teh Choon Jin } \\
\text { (2016). Mazni Alias, Roziah Mohd. Rasdi. (2015); } \\
\text { Saira Iqbal Khan, Atif Mahmood, Sara } \\
\text { Kanwal,(2015); Na-Ting Liu a \& Cherng G. Ding } \\
\text { (2011); Amanda Shantz, Kerstin Alfes, And Gary P. } \\
\text { Latha. (2014) }\end{array}$ \\
\hline Ethical climate & $\begin{array}{l}\text { Obalade \& Arogundade (2019; Leweherilla } \\
\text { Novalien C. (2017); Azlina Yassin (2011); } \\
\text { Muhammad Yasir, Amran Rasli (2018); Ana Sofia } \\
\text { Aryati , Achmad Sudiro, Djumilah Hadiwidjaja and } \\
\text { Noermijati Noermijati (2017) }\end{array}$ \\
\hline Leadership & $\begin{array}{l}\text { Muhammad Yasir, Amran Rasli (2018); Suzanne } \\
\text { van Gils, Niel Van Quaquebeke, Daan Van } \\
\text { Knippenberg, Marius Van Dijke, David De Cremer. } \\
\text { (2013); Yan_Hong Yao and Ying- Ying Fan, Yong- } \\
\text { Xing Guo,Yuan Li. (2014); Ozgur Demirtas(2015); } \\
\text { Arif Masih Khokhar, Muhammad Zia-ur-Rehman, } \\
\text { (2017); Shenjiang Mo,Junqi } \\
\text { Shi.(2015);.Mohammad Harisur Rahman } \\
\text { Howladar, Sahidur Rahman, Aftab Uddin. (2018); } \\
\text { Ana Sofia Aryati , Achmad Sudiro,Djumilah } \\
\text { Hadiwidjaja and Noermijati Noermijati, (2017); } \\
\text { Yan Liu, , Long W. “Rico” Lam, , Raymond Loi. } \\
\text { (2015); Aida Abdullah \& Sabitha Marican. (2017); } \\
\text { Hongyan Jiang, Yang Chen, Peizhen Sun and Jun } \\
\text { Yang. (2016) }\end{array}$ \\
\hline
\end{tabular}

Novalien (2017) conducted a study on deviant behaviour in Maluku, Indonesia and found that the workplace environmental and ethical culture played an important role as a triggering factor of deviant behaviour. Some of the deviant behaviours are coming late into the workplace, early departure, unauthorized exit, truancy, and hang out during working hours. There are even more serious deviant behaviours such as cases of sexual harassment and destructive behaviour of organizations such as breach of trust and corruption. This study concurs with the findings of the study engaged by Yassin (2011), where environmental ethics is one of the major factors affecting the increase of deviant behaviour among manufacturing industry workers. In addition to environmental ethics, job satisfaction and self-esteem also are the causes of the deviant behaviour demonstrated by the workers.

Among the recent studies that examined deviant behaviour at the workplace is a study conducted by Aryati et al., (2017) that investigated the influence of leadership ethics on the behaviour of workers in the organization. The detailed focus of the study is on the ethical environment and the loyalty to the organization. The negative relationship between ethical 
INTERNATIONAL JOURNAL OF ACADEMIC RESEARCH IN BUSINESS AND SOCIAL SCIENCES

Vol. 10, No. 15, Youth and Community Wellbeing: Issues, Challenges and Opportunities for Empowerment V1. 2020, E-ISSN: 2222-6990 @ 2020 HRMARS

leadership with workplace deviant behaviour became an evidence of the study and consequently, the study showed that ethical leadership can create a positive atmosphere and environment. The result of this study had also shown that ethical leadership had a significant impact on overcoming the deviant behaviour cases in organizations.

There is also a study that identifies leadership factor as a cause of deviant behaviour among workers. Gils et al., (2013) explained that leadership is a factor that can encourage or can reduce the incident of workplace deviant behaviour. The findings of the study agreed that low ethical leadership was a factor of encouragement to deviant behaviour among high performing employees compared to low-performing employees.

A study by Yilditz and Alpkan (2015) found that employees' perceptions about the organization were a predictor of their attitudes, which eventually turned into the cause of negative behaviours including deviant behaviour. In this study, the deviant behaviour shown by the workers is the result of negative attitudes and negative perceptions of workers toward the organization. The researchers also look at the effect of previous studies and found that deviant behaviour at work is increasingly becoming a threat to the organization, especially in terms of social and economic costs. In addition, employee perceptions about organizational support towards their work performance can also affect their attitudes and behaviours.

Workplace deviant behaviour had also been studied by Alias (2013) to determine the predictors of workplace deviant behaviour in which job satisfaction was investigated as the mediator in the framework. The results showed there exists a significant relationship between employee perceptions on organizational support with workplace deviant behaviour. In addition, the result showed that job satisfaction fully mediates the relationship between perceived organizational support, and job autonomy on workplace deviant behaviour. The perception of the worker is one of the sensitive factors to job satisfaction. When employees made an impression that the organization does not support their efforts, this will cause their job satisfaction to decline and they tend to exhibit it through deviant behaviour.

In addition, the research by Nasir and Bashir (2012) on workplace deviance in public sector organizations in Pakistan found that job satisfaction is significantly strongly correlated with deviant workplace behaviour. In addition, job satisfaction contributes to the increased occurrence of behaviour-related cases that violate the values and norms of the organization.

Another research in this area was conducted on workplace spirituality and its relationship with workplace deviant behaviour by Ahmad and Omar (2014). The research suggested that workplace spirituality can be a potential element to reduce deviant behaviour through job satisfaction. Radzali (2015) also studied the element of religiosity or spirituality as a moderating role in the relationship between emotional stability, workload, job stress, and workplace deviant behaviour. The study showed that religiosity or spirituality plays a moderating role in the relationship between emotional stability and workplace deviant behaviour but does not moderate the relationship to job stress and workload.

Bhatti, Alam, Hassan and Sulaiman (2016) had a study on Islamic spirituality and Islamic social responsibility in reducing workplace deviant behaviour and found that these two elements can influence an employees' in reducing their deviant behaviour at the workplace. 
The study by Ahmad (2014) concluded that the organization should pay attention to the role conflict among the workers. This is because role conflict is an element that has the potential to contribute to the improvement of workplace deviant behaviour in the organization. In addition, work pressure, workload, and unclear job description also have significant relationship with workplace deviant behaviour.

The study by Wan (2015) that focussed on employees in the customer service division found that there was significant relationship between work stress and deviant behaviour in the workplace. The findings can lead to a new study that should examine different contexts and different populations as well as other factors that may potentially constitute a source of employee devious behaviour in the workplace.

Moreover, previous studies by Farhadi (2011) showed that there is a positive relationship between work stress and workplace deviant behaviour. In the findings, there is a difference between deviant behaviour based on demographic factors. This shows that individual differences also influence the form of workplace deviant behaviour among employees.

\section{Future outlook of deviant behaviour at workplace}

The study on deviant behaviour at workplace is widely discussed by researchers on employees in different organizations. However, to date studies on workplace deviant behaviour had been carried out on limited population despite its' importance. In the Malaysian context, for instance, studies on workplace deviant behaviour focused on manufacturing employees (Abdul, 2008; Azlina, 2011), staff in Malaysian Local Council (Mazni, 2014), workers in Education Ministry (Hadi, 2011) and officers in public enforcement organization (Malini, 2016). There is a dire need to expand the population to young employees as well as expanding the scope to government servants since they are the main group of employees in many countries. Moreover, researchers like Alias (2013); Farhadi (2011); and Radzali (2015) have studied workplace deviant behaviour on government employees but the focus group is not determined by job position and young staff. Lately, workplace deviant behaviour is becoming an issue not only on the lower-grade staff but also those at the top management group. Without a doubt, each category will have its unique contributing factors as displayed in the past studies. Thus, it is mandatory for more research to be carried out based on specific population of the public sector to enrich the knowledge on workplace deviant behaviour.

Theoretically and past models reviewed show that the construct of workplace deviant behaviour could be specified into two main dimensions, namely, organization and individual. Further analysis showed that the organization dimension constitutes factors like organization climate, ethical leadership, and perceived organization support. On the other hand, the individual dimension would have factors such as job satisfaction, work stress, and spirituality. Future studies could investigate the workplace deviant behaviour among young workers in the public sector by giving due attention to the dimension of organization and individual. This would propel towards finding more effective solutions to reduce the problems associated with workplace deviant behaviour.

The eight goals of 2030 Agenda for Sustainable Development calls for decent work and economic growth especially among young people. Undoubtedly, lesser workplace deviant behaviour will lead towards higher productivity as well as economic growth. Thus, more efforts should be placed among researchers and policy makers to identify issues and seek solutions to bring workplace deviant behaviour under control especially among young employees at the public sector. Regulating 
INTERNATIONAL JOURNAL OF ACADEMIC RESEARCH IN BUSINESS AND SOCIAL SCIENCES

Vol. 10, No. 15, Youth and Community Wellbeing: Issues, Challenges and Opportunities for Empowerment V1. 2020, E-ISSN: 2222-6990 @) 2020 HRMARS

workplace deviant behaviour will definitely boost government resources to be utilized effectively to bring growth and prosperity to the society as a whole.

\section{Conclusion}

Undoubtedly, workplace deviant behaviour is one of the problems that exist in every organization and it requires the attention and action of all parties to cope with it. The cause of the deviant behaviour can weaken the overall performance of the organization and will tarnish the image and give a bad impression to the organization. The various factors of workplace deviant behaviour among workers in an organization are employee personality, stress and workload, job satisfaction, employee perceptions of organizational support, leadership ethics, environment and work culture as well as the spiritual level of the employee itself. The study implies that the construct of workplace deviant behaviour has a huge impact on sustainable development goals as well effective utilization of government resources. Thus, it is recommended that more studies on workplace deviant behaviour should be conducted, particularly among young employees in the government sector, to ensure optimization of quality and integrity at workplace as well as overcoming the malaise of corruption.

\section{References}

Ahmad, A., \& Omar, Z. (2014). Reducing deviant behaviour through workplace and job satisfaction. Asian Social Sciences 10(9):107-112. Retrieved 19 July 2018 from http://dx.doi.org/10.5539/ass .v10n19p107.

Ahmad, Z. I. K. (2014). Workplace deviant behaviour: Study on bank employees in Klang Valley. Thesis Universiti UUM: Malaysia.

Alias, M. (2013). Predictors of workplace deviant behaviour and the mediating role of job satisfaction. Thesis University Putra Malaysia (UPM): Malaysia.

Anderson, S. E., Coffey, B. S., \& Byerly, R. T. (2002). Formal organizational initiatives and informal workplace practices: links to work-family conflict and job-related outcomes. Journal of Management, 28(6), 787-810.

Appelbaum, S. H., Laconi, G. D., \& Matousek, A. (2007), Positive and negative deviant workplace behaviour: Causes, impacts and solutions. Corporate Governance, 7(5) 586-598.

Appelbaum, S. H., \& Roy-Girard, D. (2007), Toxins in the workplace: Effect on organizations and employees. Corporate Governance 7 (1):17-28.

Appelbaum, S. H., Deguire, K. J., \& Lay, M. (2005), The relationship of ethical climate to deviant workplace behaviour. The International Journal of Business in Society. 5 (4): 43-55.

Aryati A., S., Sudiro, A., Hadiwidjaja, D., \& Noermijati, N. (2017). The influence of ethical leadership to deviant behaviour mediated by ethical climate and organizational commitment. International Journal of Law and Management. 60 (2): 233-249.

Awang, Z., \& Ariffin, T. J. (2012). Research proposal. A comprehensive guide in writing a research proposal. UiTM Press.

Bagheri S. M., \& Shahroodi H. M. (2014). The Relationship between organizational justice and deviant behaviour in the workplace (Case study: Employees in university of Isfahan). Asian Journal of Research in Social Sciences and Humanities. 4 (9): 201-216. Retrieved 19 July 2018 from https://www.researchgate.net/publication/269739744_The_relationship_between_pe 
rceived_organizational_justice_and_deviant_behaviour_in_the_workplace_Case_study_Empl oyees_in_university_of_Isfahan.

Baron, R. A., \& Neuman, J. H. (1996). Workplace violence and workplace aggression: Evidence on their relative frequency and potential cause. Aggressive Behaviour, 22 (3): 161-173.

Bennet, R. J., \& Robinson, S. L. (2000), Development of a measure of workplace deviance. Journal of Applied Psychology, 85(3); 349-360.

Bolin, A., \& Heatherly, L. (2001), Predictors of employee deviance: The relationship between bad attitudes and bad behaviour. Journal of Business and Psychology, 15(3):405-418.

Brayfield, A. H., \& Rothe, H. F. (1951). An index of job satisfaction. Journal of Applied Psychology, 35(5): 307-311.

Demir, M. (2011). Effects of organizational justice, trust and commitment on employees' deviant behaviour. An International Journal of Tourism and Hospitality Research. 22 (2):204-221.

Dunlop, P. D., \& Lee, K. (2004), Workplace deviance, organisational citizenship behaviour and business unit performance. The bad apples do spoil the whole barrel. Journal of Organisational Behaviour, 25(1), 67-80.

Eisenberger, R., Cummings, J., Armeli, S., \& Lynch, P. (1997), Perceived organizational support, discreationary treatment, and job satisfaction. Journal of Applied Psychology 1997, 82(5): 812820.

Estes, B., \& Wang, J. (2008). Workplace incivility: Impacts on individual and organisational performance. Human Resource Development Review, 7 (2):218-240.

Everton, W. J., Jolton, J. A., \& Mastrangelo, J. A. (2007), Be nice and fair or else: understanding reasons for employees deviant behaviour, Journal of Management Development, 26(2): 117-131. Retreived 12 March 2019 from https:// www.emerald.com/ insight/content/doi/10. 1108/02621710710726035/full/html.

Farhadi, H., Omar, F., Nasir R., Zarnaghash, M., \& Salehi, M. (2015). The role of demographic factors on workplace deviant behaviour. International Conference on Social Sciences \& Humanities (ICOSH-UKM2012). Journal of Social Sciences and Humanities. Special Issue (2): 032-039.

Farhadi, H., Nasir, R., Omar, F., \& Nour, A. (2015). Understanding employees' deviant behaviour: The role of agreeableness and stress related to work. eBangi:Journal Of Human Sciences and Humanities. 2(1):102-107

Farhadi, H. (2011). The role of job stress, job satisfaction and individual differences on workplace deviant behaviour. Unpublished thesis, Universiti Kebangsaan Malaysia.

Giacalone, R. A., \& Greenberg, J. (1997). Antisocial behaviour in organizations. Thousand Oaks: Sage Publications

Gill, H., Meyer, J. P., Lee, K., Shin, K. H., \& Yoon, C. Y. (2011). Affective and continuance commitment and their relations with deviant workplace behaviours in Korea. Asia Pacific Journal of Management. 28 (3): 595-607.

Gils, S. V., Quaquebeke, N. V., Knippernberg, D. V., Dijike, M. V., \& Cremer, D. D. (2013). Ethical leadership and follower organizational deviance: The moderating role of follower moral attentiveness. The Leadership Quarterly. 26 (2): 190-203.

Golpavar, M. (2015). Unconventional functions of deviant behaviours in the relationship between job stress and emotional exhaustion: Three study findings. Current Psychology. 35 (3): 269-284. 
INTERNATIONAL JOURNAL OF ACADEMIC RESEARCH IN BUSINESS AND SOCIAL SCIENCES

Vol. 10, No. 15, Youth and Community Wellbeing: Issues, Challenges and Opportunities for Empowerment V1. 2020, E-ISSN: 2222-6990 @) 2020 HRMARS

Golparvar, M., \& Nadi, M. A. (2011). Mediating role of organizational loyalty in relation between work ethic with deviant workplace behaviour. Journal Ethics in Sciences \& Technology. 6 (1): 43-52.

Gruys, M. L., \& Sackett, P. R. (2003), Investigating the dimensionality of counterproductive work behaviour, International Journal of Selection and Assessment 11(1): 31-42.

Gruys, M. L. (1999), The dimensionality of deviant employee behaviour in the workplace, PhD Thesis, University of Minnesota, USA.

Haldorai, K., Kim, W. G., Chang, H. S., \& Li, J. J. (2020), Workplace spirituality as a mediator between ethical climate and workplace deviant behaviour. International Journal of Hospitality Management. 86(102372):1-5. Retrieved 30 August 2020 from https://doi.org/10.1016/j.ijhm. 2019.102372.

Henle, C. A., Giacalone, R. A., \& Jurkiewicz, C. L. (2005). The role of ethical in workplace deviance. Journal of Business Ethics, 56: 219-230.

Hollinger, R. C. (1986). Acts against the workplace: social bonding and employee deviance. Deviant Behaviour. 7: 53-75.

Hunt, S. T. (1996) Generic work behaviour: An Investigation into the dimensions of entry-level, hourly job performance. Personnel Psychology. 49, 51-83.

Jones, J. W. (1980). Attitudinal correlates of employees' deviance: Theft, alcohol us, and nonprescribed drug use. Psychological Reports. 47, 71-77.

Joseph, C. (2020). What are common kinds of workplace deviance? Available: https://small business.chron.com/common-kinds-workplace-deviance-10178.html

Kalshoven, K., Den, H. D. N., De \& Hoogh, A. H. B. (2011). Ethical leadership at work questionnaire (ELW): Development and validation of a multidimensional measure. The Leadership Quarterly 22, (2011) 51-69.

Kaptein, M. (2011) Understanding unethical behaviour by unravelling ethical culture. Human Relations. 64(6), $843-869$.

Khattak, M. N., Bashir, Khan, M., Fatima, T., \& Ali, S. S. Y. (2018). The underlying mechanism between perceived organizational injustice and deviant behaviours: Moderating role of personality traits. Asia Pacific Management Review. xxx (2018): 1-11.

Leweherilla, N. C. (2017). The antecedents of deviant workplace behaviours on the employees of Regional Apparatus Organization (ODN) in Maluku Province, Indonesia. Russian Journal of Agricultural and Socio-Economic Sciences. 06 (19):165-174.

Mangione, T. W., \& Quinn, R. P. (1975). Job satisfaction, counter-productive behaviour and drug use at work. Journal of Applied Psychology, 60, 114-116.

Shamsudin, M. F., Chandrakantan, S., \& Ibrahim, H. (2011). HR practices and deviant behaviour at work: An exploratory study. 2011 International Conference on Business and Economics Research IPEDR Vol. 16. IACSIT Press: Singapore.

Na-Ting, L., \& Cherng, G., D. (2012). General ethical judgements, perceived organizational support, interactional justice, and workplace deviance. The International Journal of Human Resourse Management. 23 (13):2712-2735.

Nasir, M., \& Bashir, A. (2012). Examining workplace deviance in public sector organizations in Pakistan. International Journal of Social Economics, 39 (4):240-253.

Norsilan, I. N., Omar, Z., \& Ahmad, A. (2014). Workplace deviant behaviour: A review of typology of workplace deviant behaviour. Middle-East Journal of Scientific Research 19 (Innovation 
Challenges in Multidisciplinary Research \& Practice) : 34-38. Retrieved 25 July 2018 from DOI: 10.5829/idosi.mesjr.2014.19.icmrp.6.

Obalade, G. O., \& Arogundade, K. K. (2019). Ethical climate and deviant behaviour among employees of selected public and private universities: The case of the emerging Country. Corporate Governance and Organizational Behaviour Review. 3 (2): 30-39

O’Neil, T. A., Lewis, R. J., \& Carswell, J. J. (2011). Employee personality. Justice perceptions, and the prediction of workplace deviance. Personality and Individual Differences. 51 (5): 595-600.

Omar, F., Halim, F. W., Zainah, A. Z., Farhadi, H. Nasir, R., \& Khairudin, R. (2011). Stress and job satisfaction as antecedents of workplace deviant behaviour. World Applied Sciences Journal 12 (Special Issues of Social and Psychological Sciences for human Development): 46-51.

Pallant, J. (2007). SPSS survival manual. A step by step guide to data analysis using SPSS for Windows, third edition. McGraw Hill, Open University Press.

Radzali, F. M. (2015). Factors associated with workplace deviant behaviour in a public organization in Malaysia and moderating role of religiosity. Master Thesis, Universiti Putra Malaysia.

Raelin, J. A. (1994). Three scales of professional deviance within organizations. Journal of Organizational Behaviour, 15, 483-501.

Rahman, S., Ferdausy, S., \& Karan, R. (2012) Relationship among emotional intelligence, deviant workplace behaviour and job performance: An empirical study. Portuguese Journal of Management Studies. XVII (1): 39-61.

Robinson, S. L., \& O'Leary-Kelly, A. (1996). Monkey see, monkey do: The role of role models in predicting workplace aggression. In J.B Keys \& L.N. Dosier (Eds.). Academy of Management 1996(1):288-292.

Robinson, S. L., \& Bennet, R. J. (1995), A typology of deviant workplace behaviours: A multidimensional scaling study. Academic of Management Journal 38(2), 555-572.

Quoquab, F., \& Mohammad, J. (2018). Crafting literature review: a guide for doctoral students, $2^{\text {nd }}$ Edition: Pearson Malaysia Sdn Bhd.

Schwepker, C. H., Ferrell, O. C., \& Ingram, T. N. (1997), The influence of ethical climate and ethical conflict on role stress in sales force. Journal of the Academy of Marketing Science. 25 (20): 99108.

Sathappan, M., Omar, Z., Ahmad, A., Hamzah, A., \& Arif, I. (2016). Exploring types of deviant workplace behaviour in a public organization in Malaysia. Journal of Social Sciences Research. $10(3): 2146-2155$.

Sims, R.L. (2002), Ethical rule breaking by employees: a test of social bonding theory, Journal of Business Ethics, 40(2): 101-109.

Skarlicki, D. P., \& Folger, R. (1997), Retaliation in the workplace: The roles of distributive, procedural, and interactional justice. Journal of Applied Psychology, 82, 434-443.

Slora, K. B. (1989). An Empirical approach to determining employee deviance base rates. Journal of Business and Psychology, 4(2), 199-218.

Tuna, M., Ghazzawi I., Yesiltas, M., Tuna, A. A., \& Arslan, S. (2015). The effects of the perceived external prestige of the organization on employee deviant workplace behaviour, the mediating role of job satisfaction. International Journal of Contemporary Hospitality Management. 28 (2): 366-396. 
Underwood, L. G. (2011). The Daily Spiritual Experience Scale: Overview and Results. Religions (2): 29-50. Retreived 12 March 2019 from https://www.semanticscholar. org/paper/The-DailySpiritual-Experience-Scale\%3A-OverviewandUnderwood/20e0c9d55453fc19ea07bab7924632 ae0a5adebb.

Wan, D. W. U. H. (2015). Occupational stress and deviant workplace behaviour among customer services employees of call center in Malaysia. Unpublished thesis UUM: Malaysia.

Yassin, A. (2011). Deviant behaviour at workplace. Unpublished thesis UUM: Malaysia.

Yilditz, B., \& Alpkan, L. (2015). A theoretical model on proposed predictors of destructive deviant workplace behaviours and the mediator role of alienation. Procedia-Social and Behavioural Sciences. 210 (2015): 330-338. 